\title{
Mesin Pencacah Cengkeh
}

\author{
Ah. Sulhan Fauzi ${ }^{1}$, Engga Predianto ${ }^{2}$, Fatkur Rhohman ${ }^{3}$ \\ 1,2,3Teknik Mesin, Fakultas Teknik, Universitas Nusantara PGRI Kediri \\ 1'sulhanfauzi@unpkediri.ac.id, 3fatkurrohman@unpkediri.ac.id
}

\begin{abstract}
ABSTRAK
Telah dirancang mesin pencacah cengkeh untuk skala home industry dengan modifikasi model pisau dan sistem perajangan. Perancangan mesin menggunakan variasi model pisau, pisau pertama berbentuk memanjang horisontal dengan dimensi alas pisau $15 \mathrm{~mm}$, tinggi pisau $3 \mathrm{~mm}$, panjang $150 \mathrm{~mm}$. Pisau kedua dengan bentuk zigzag horisontal dengan dimensi alas pisau $20 \mathrm{~mm}$, tinggi $3 \mathrm{~mm}$, panjang $50 \mathrm{~mm}$. Modifikasi bentuk pisau ini diharapkan memberikan perbedaan hasil cacahan yang halus dan teratur. Dalam perancangan mesin pencacah cengkeh ini juga ditentukan daya motor yang akan digunakan yaitu 0,4625 HP pada putaran $1.400 \mathrm{Rpm}$. Perancangan mesin pencacah cengkeh ini diharapkan bisa menghasilkan mesin yang sederhana dan mudah digunakan dengan kualitas yang baik, untuk kapasitas pencacahan kurang lebih $5 \mathrm{~kg} / \mathrm{jam}$. Dengan menggunakan mesin pencacah ini dalam jangka panjang diharapkan bisa membantu meningkatkan pendapatan masyarakat di daerah penghasil cengkeh.
\end{abstract}

Kata Kunci: model pisau, sistem perajangan, hasil cacahan.

\begin{abstract}
It has been designed clove slicer machine for home industry scale with knife modification and slicer system. The machine used a variation of the knife model, the first knife was horizontally elongated with the dimensions of the knife layer 15 $\mathrm{mm}, 3 \mathrm{~mm}$ height, $150 \mathrm{~mm}$ length and the knife length $50 \mathrm{~mm}$. The second knife with a horizontal zigzag with the dimensions of the layer knife $20 \mathrm{~mm}, 3 \mathrm{~mm}$ height, $50 \mathrm{~mm}$ long. The modification of knife shape is expected to give the good difference and orderly sliced results. In designed of this machine also determined the clove slicer force motor power, it will be used $0.4625 \mathrm{HP}$ at 1,400 Rpm. The design of clove slicer machine is expected to produce a simple and easy to use machine in good quality, for slicering capacity of approximately $5 \mathrm{~kg} / \mathrm{hour}$. In the future, using this slicer machine is expected to improve income of the clove-producing societies.
\end{abstract}

Keywords: knife, slicer system, sliced result. 


\section{PENDAHULUAN}

Indonesia merupakan

negara agraris, yang sebagian besar penduduknya adalah petani. Cengkeh adalah salah satu hasil pertanian/ perkebunan yang dikelola secara besar-besaran oleh industri rokok khususnya di wilayah jawa timur yang terdapat banyak pabrik rokoknya. Selain dikelola industri rokok, cengkeh juga menjadi salah satu sumber pendapatan bagi masyarakat petani cengkeh kita dengan cara menjual langsung hasil tanamnya atau dengan mengolahanya lebih dahulu. Pengolahan yang dilakukan biasanya dengan mencacah cengkeh secara manual menggunakan gunting maupun ditumbuk, dalam proses seperti ini membutuhkan waktu yang relatif lama, yaitu untuk $1 \mathrm{~kg}$ cengkeh butuh waktu sekitar 30 menit. Hal itulah yang melatarbelakangi perlunya perancangan alat atau mesin untuk memperbaiki proses pencacahan sehingga menghasilkan cacahan cengkeh yang lebih halus dan sekaligus meningkatkan kapasitas produksinya.

Cengkeh merupakan salah satu tanaman perkebunan yang penting bila dibandingkan dengan tanaman perkebunan lain. Produksi cengkeh yang telah dewasa setaraf dengan karet, kelapa sawit, dan kopi. Tetapi tanaman cengkeh yang telah lanjut usia produksinya jauh meningkat, jadi lebih menguntungkan [1]. Di Indonesia banyak sekali ditemukan tipe-tipe tanaman cengkeh dan diantara satu dengan yang lainnya sulit dibedakan. Misalnya cengkeh tipe ambon, tipe raja, tipe indari, tipe dokiri, tipe cengkih afo, dan tipe tauro. Perkawinan antara berbagai tipe itu membentuk tipe baru yang sulit digolongkan. Pada umumnya, cengkeh dijadikan bahan masakan. Di Indonesia cengkeh menjadi bahan masakan yang paling sering digunakan. Selain menjadi bahan masakan, tanaman tropis yang berasal dari Maluku ini sudah banyak dibudidayakan untuk diambil bunga dan minyaknya. Minyak cengkeh (Eugniae aromatica) dapat dihasilkan dari penyulingan serbuk kuntum cengkeh kering (clove oil), serbuk tangkai kuntum cengkeh (clove stem oil), dan daun cengkeh kering (clove leaf oil). Minyak cengkeh banyak dimanfaatkan oleh dokter gigi sebagai penghilang rasa sakit. Selain itu, tanaman ini juga digunakan dalam industri farmasi, dan wewangian.

Untuk mempermudah pengolahan cengkeh diperlukan mesin pencacah cengkeh. Mesin pencacah cengkeh ini mencacah cengkeh yang masih berbentuk bunga cengkeh menjadi cacahan cengkeh yang halus dan siap untuk di produksi [2]. Mesin pencacah cengkeh ini dapat bekerja apabila poros mesin dapat berputar. Dimana poros mesin sebagai sumber pengerak dari semua komponenkomponen yang ada, tenaga pengerak berputar dan terus dilanjutkan atau di transmisikan putaran ke pulley dengan mengunakan Sabuk/ V-belt memutar 
pulley kedua yang dihubungkan ke poros pencacah.

Dalam perancangan Mesin pencacah cengkeh didasarkan pada kebutuhan untuk lebih meningkatkan produktifitas dan efektifitas penyediaan cacahan cengkeh. Mesin pencacah cengkeh ini memasangkan motor listrik secara horisontal. Berdasarkan analisis tuntutan calon pengguna diperoleh beberapa pernyataan kebutuhan terhadap mesin tersebut antara lain:

a. Konstruksi mesin yang kuat, kokoh dan dapat dipindahpindah.

b. Mudah dalam penggunaan dan perawatan.

c. Sumber tenaga (motor listrik) sesuai dengan kinerja mesin dan tidak boros biaya listrik

\section{METODE PENELITIAN}

Penelitian ini dilakukan
dengan perancangan dan
pembuatan produk. Pada tahap
perancangan pertama dilakukan
dengan menggambar sketsa dari
produk yang akan dibuat. Gambar
sketsa hasil perancangan yang telah
dibuat bisa dilihat pada gambar 1.

Selanjutnya dilakukan perancangan spesifikasi alat yang akan dibuat, yaitu perhitungan kapasitas produksi, meliputi perhitungan kecepatan keliling pencacah, perancangan pulley, yaitu komponen yang digunakan untuk memindahkan daya dari poros satu ke poros yang lain dengan mengunakan alat bantu sabuk. Karena perbandingan kecepatan dan diameter pulley berbanding terbalik, maka pemilihan pulley yang baik dilakukan dengan teliti agar

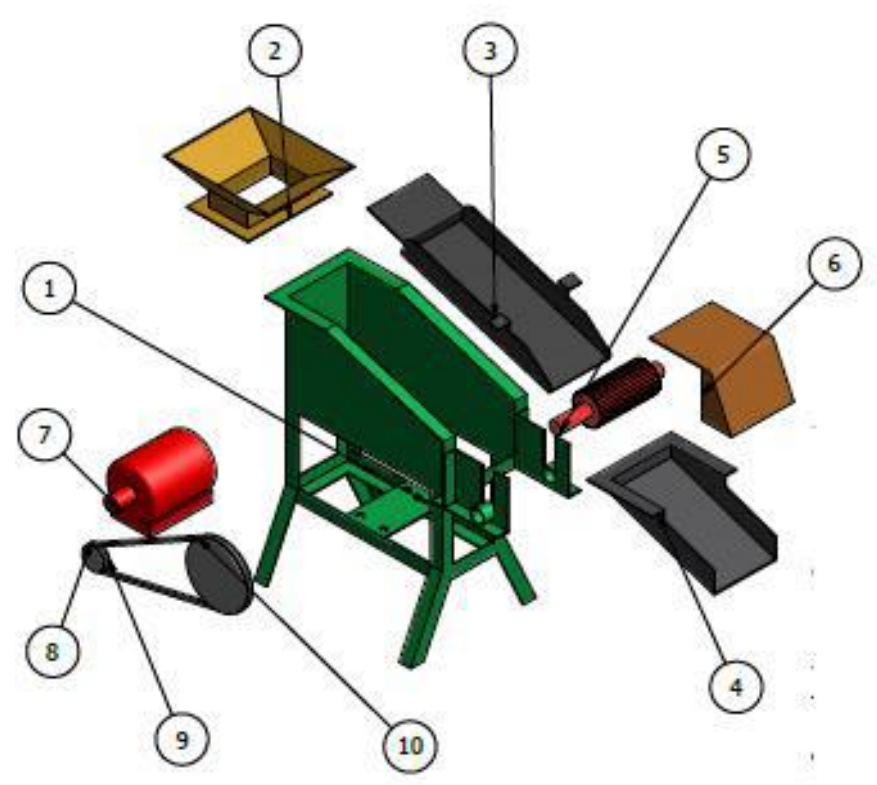

Gambar 1. rancangan mesin pencacah cengkeh 
mendapatkan perbandingan kecepatan yang diinginkan. Diameter luar digunakan untuk alur sabuk dan diameter sabuk dalam untuk penampang.

Sabuk/ V-belt, adalah sabuk yang tidak berujung dan diperkuat dengan penguat tenunan dan tali. sabuk/ V-belt ini terbuat dari karet dan bentuk penampangnya berupa trapesium. Bahan yang digunakan untuk membuat inti sabuk itu sendiri adalah terbuat dari tenunan tetron. Penampang pulley yang digunakan berpasangan dengan sabuk juga harus berpenampang trapesium juga. Pulley merupakan elemen penerus putaran yang diputar oleh sabuk penggerak.

\section{Perancangan poros} dilakukan untuk menentukan ukuran diameter poros, berdasarkan parameter rancang bangun poros, dengan menggunakan rumus kekuatan bahan yang ada. Poros yang umumnya meneruskan daya melalui sabuk, pully, akan mendapatkan beban puntir dan lentur, torsi, Momen puntir ekuivalen, Momen bending ekuivalen.

Keterangan gambar 1 :

1. Rangka plat $L$

2. Cerobong masuk

3. Landasan

4. Cerobong keluaran

5. Pisau

6. Tutup pisau

7. Motor

8. Sabuk/ V-belt

9. Pulley 1

10. Pulley 2
Perancangan pasak, yaitu suatu elemen mesin yang biasa dipakai untuk menetapkan bagianbagian mesin, seperti: bearing, roda gigi, pulley, kopling pada poros. Momen diteruskan dari poros ke naf atau dari naf ke poros.

Pasak dapat digolongkan menurut letaknya pada poros. Tetakhir perancangan bantalan, yaitu elemen mesin yang mampu menumpu poros berbeban, sehingga gesekan bolak baliknya dapat berlangsung secara halus, aman dan panjang usia pemakaiannya. Bantalan harus cukup kokoh untuk memungkinkan poros suatu mesin bekerja dengan baik [3].

\section{HASIL DAN PEMBAHASAN}

Mesin pencacah cengkeh yang digunakan dalam perancangan ini memiliki diameter tabung pencacah $75 \mathrm{~mm}$ dan kapasitas pencacahan $5 \mathrm{~kg} /$ jam dengan kecepatan putar 1.400 Rpm, sehingga didapat kecepatan putar $5,5 \mathrm{~m} / \mathrm{s}$. Selanjutnya perancangan pulley.

Untuk sabuk tipe A diketahui ukuran pulley $e=15 \mathrm{~mm}, \mathrm{f}=10 \mathrm{~mm}$ dengan jumlah sabuk $(n)=1$. Dengan putaran motor $1.400 \mathrm{Rpm}$ didapat data diameter pulley penggerak (dp1) $50,5 \mathrm{~mm}$ dan diameter pulley pencacah $150 \mathrm{~mm}$, sehingga didapat putaran pulley tabung pencacah 471 Rpm, lebar pulley $20 \mathrm{~mm}$, volume pulley $18.840 \mathrm{~mm} 3$ dan berat pulley $1,35648 \mathrm{~kg}$. Rancangan pulley bisa dilihat pada gambar 2 . 


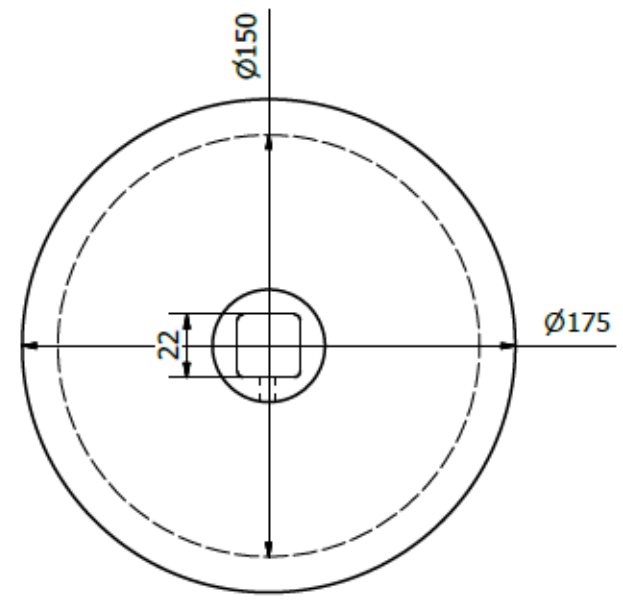

Gambar 2. Rencana pulley yang digerakan

Untuk sabuk/ V-belt, kecepatan liniernya didapat $3,69 \mathrm{~m} / \mathrm{s}$, panjangnya $336 \mathrm{~cm}$, sehingga jenis sabuk yang digunakan adalah V-belt A33 dengan panjang $336 \mathrm{~cm}$ dan berat $0,1 \mathrm{~kg}$.

Poros pencacah yang digunakan mempunyai dimensi panjang $275 \mathrm{~mm}$ dan diameter 14 $\mathrm{mm}$. Dari data dimensi tersebut didapat volume poros $6.044,5 \mathrm{~mm} 3$; massa poros $4,7 \mathrm{~kg}$. Poros pulley yang digunakan mempunyai panjang $30 \mathrm{~mm}$ dan diameter $20 \mathrm{~mm}$, sehingga diperoleh data volume 942 mm3 ; massa $7,8 \mathrm{~kg}$; berat $4,77 \mathrm{~kg}$ dan torsi $0,47 \mathrm{~kg} / \mathrm{mm}$.

Perancangan pasak dilakukan dengan merencanakan diameter dudukan pulley yang akan digunakan berukuran $20 \mathrm{~mm}$, sehingga didapat kecepatan keliling $1,465 \mathrm{~m} / \mathrm{s}$; gaya pada pasak $6,30 \mathrm{~kg}$; lebar pasak $5 \mathrm{~mm}$; tebal pasak 3,33 $\mathrm{mm}$; panjang pasak $31,4 \mathrm{~mm}$; tegangan geser $0,40 \mathrm{~kg} / \mathrm{mm}$.
Rancangan bantalan yang akan digunakan dimulai dengan merencanakan beban ekivalen ( $\mathrm{Pr}$ ) 248,3 kg; kemudian faktor kecepatan (Fn) $0,023 \mathrm{~m} / \mathrm{s}$; faktor umur (Fh) 0,00044; dan umur nominalnya (Lh) 0,6627 jam. Selanjutnya perancangan pisau, jumlah pisau yang digunakan 15 , dengan dimensi panjang $400 \mathrm{~mm}$, alas $40 \mathrm{~mm}$ dan tinggi $100 \mathrm{~mm}$. Sehingga didapat volume $13.500 .000 \mathrm{~mm}$.

\section{SIMPULAN}

Perancangan mesin pencacah cengkeh yang sudah dilakukan menghasilkan mesin pencacah dengan spesifikasi, kapasitas produksi $5 \mathrm{~kg} / \mathrm{jam}$. Material untuk mesin pencacah cengkeh ini mengunakan besi. Kerangka mesin dengan dimensi panjang $43 \mathrm{~cm}$, lebar $16 \mathrm{~cm}$, tinggi depan $50 \mathrm{~cm}$, dan tinggi belakang $60 \mathrm{~cm}$. Dimensi tabung ini berdiameter dalam $3 \mathrm{~cm}$, panjang tabung $7,5 \mathrm{~cm}$.. Untuk sistem 
transmisi mesin pencacah cengkeh mengunakan tenaga pengerak berupa motor listrik 0,4625 HP 1.400 rpm menjadi $471 \mathrm{rpm}$ dengan

\section{DAFTAR PUSTAKA}

[1] Sudarmo, S, 2005. Pestisida Nabati Pembuatan Dan Pemanfaatannya.

Yogyakarta, Kanisius.

[2] Sujarwoko, Destyan H. 2005. Meningkatkan Produktifitas Petani Cengkeh Jawa Timur .www.antarajatim.co komponen berupa 2 pulley berdiameter $50,5 \mathrm{~mm}$ dan $150 \mathrm{~mm}$, V-belt jenis A33 dan 1 poros diameter $14 \mathrm{~mm}$ dan panjang $275 \mathrm{~mm}$.

[3] Sularso, Suga, Kiyokatsu. 1985. Dasar Perencanaan Dan Pemilihan Elemen Mesin, Jakarta: Pradnya Paramita. 